\title{
Research Paper Constraints to consuming nutrient rich food in Koppal district of Karnataka
}

\section{- RAGHAVENDRA CHOURAD, V.R. KIRESUR AND RAGHAVENDRA KONDAGURI}

See end of the paper for authors' affiliations

Correspondence to :

\section{RAGHAVENDRA}

\section{CHOURAD}

Department of

Agricultural Economics,

College of Agriculture,

University of Agricultural

Sciences, DHARWAD

(KARNATAKA) INDIA

Email: raghu0467@gmail.com

\section{Paper History :}

Received : 03.02 .2014

Revised : 21.07.2014;

Accepted: 05.08 .2014
ABSTRACT : The word 'food' refers to the chemical substances taken into the body in order to keep the body in a healthy and active condition. The body requires food for growth, repair and replacement of its worn-out tissues. Hence, food has to provide the required raw material, energy and other regulating substances, like vitamins and minerals, for the smooth functioning of the body, besides meeting the calorific requirements like carbohydrates, proteins, fats, etc. (Pavithra, 2008). In this regard, the present study is an attempt for constraints to consuming nutrient rich food in Koppal district of Karnataka state. The study revealed that majority of the respondents found groundnut, fruits and nuts, vegetables, milk and milk products, egg and meat as expensive. Some of the respondents did not like consuming rice, wheat and ragi. Many respondents felt that edible oil is not suitable for health, while spices were uneasy for digestion. Some of the respondents did not have any awareness about consuming the processed products and beverages.

KEY WORDS : Constraints, Nutrient rich food

HOW TO CITE THIS PAPER : Chourad, Raghavendra, Kiresur, V.R. and Kondaguri, Raghavendra (2014). Constraints to consuming nutrient rich food in Koppal district of Karnataka. Internat. Res. J. Agric. Eco. \& Stat., 5(2) : 245-248. 